a subcommittee to suspend is not the same as a vote by a majority of at least a quorum of the IACUC at a convened meeting to suspend an activity. The IACUC never voted to suspend the activity.

Happy Trails is not part of Great Eastern's animal care program, and Great Eastern does not own the animals at the WRO. How does Happy Trails' alleged failure to comply with the provisions of the Animal Welfare Act regulations make Great Eastern noncomplaint with the same? Great Eastern can be faulted for failing to pay attention to what was going on and for not spelling out the obligations and responsibilities of the two parties; however, it should not be cited for its tenant's negligence. While Happy Trails' staff should have been more diligent in the care of animals under their custody, it is not certain how that is related to Great Eastern's registration, veterinary care program or IACUC function. It is not even clear that there should be an IACUC (or IACUC activity) at Happy Trails. If that is the case, how can Happy Trails be cited for conducting activities without IACUC approval?

Certainly, Great Eastern should define its relationships with Happy Trails. This occasion should provide a great teaching moment about animal welfare to all parties. The student who contacted Gusset should be commended for taking the initiative to assure that the welfare concerns of an injured animal were definitively addressed. Gusset did the right thing in immediately euthanizing the injured animal and sharing the situation with the IACUC. The IACUC acted appropriately in investigating the concern; however, much of the aggravation could have been avoided by getting engaged from the beginning and ensuring that all parties understood their obligations. Great Eastern should appeal the citation.

1. U.S. Department of Agriculture. Animal and Plant Health Service. Licensing and Registration Under the Animal Welfare Act: Guidelines for Dealers, Exhibitors, Transporters, and Researchers. (US Department of Agriculture, Washington, DC, 1992, revised 2004). <http://www.aphis.usda.gov/animal_welfare/ downloads/aw/awlicreg.pdf>

2. Animal Welfare Regulations. 9 CFR, Chapter 1 , Subchapter A, Parts 1-4, Section 2.31.

3. Public Health Service. Policy on Humane Care and Use of Laboratory Animals - Frequently Asked Questions. IACUC Composition, Functions and Authority, Question No. 9. (US Department of Health and Human Services, Washington, DC, 2006; revised 2009). <http://grants.nih.gov/ grants/olaw/faqs.htm\#IACUC_9>

Owiny is University Veterinarian and Ostmeyer is Animal Program Coordinator in the Office of Vice President for Research at Colorado State University, Ft. Collins, CO.

\section{RESPONSE}

\section{Hands off}

\section{Leslie Birke, DVM \& Reynaldo Gonzalez, DVM}

For the sake of discussion, let's assume Great Eastern's assurance statement does not specifically include the wildlife rehabilitation organization (WRO). In this case, Happy Trails is a separate entity, and Great Eastern should have handled the situation differently. Unfortunately, the IACUC's involvement, though well intentioned, is likely what led the veterinary officer to believe that the WRO was an entity under Great Eastern's institutional umbrella and to issue the citation.
Appealing the citation would be appropriate. First, Great Eastern could argue that the animals at the WRO are excluded from the Animal Welfare Act. Section 9 CFR 1.1 defines an animal as "any live or dead, dog, cat, nonhuman primate, guinea pig, hamster, rabbit, or any warm blooded animal which is used for research, teaching, testing, experimentation, or exhibition purposes or as a pet" ${ }^{\text {. }}$ Because the animals at Happy Trails are not used for any of these purposes, they are not covered by the Animal Welfare Act. Second, although, 9 CFR 2.3 (a) states "each applicant must demonstrate that his or her premises and any animals, facilities, vehicles, equipment, or other premises used or intended for use in the business comply with the regulations and standards"1, Great Eastern University could argue that the building used by the WRO wasn't part of Great Eastern's research enterprise; the WRO animals are not the property of the university, and therefore the university is not responsible for them.

Several actions should have been taken to delineate the relationship between the WRO and Great Eastern University.

\title{
A word from USDA
}

In response to the issues raised in this scenario, the United States Department of Agriculture, Animal and Plant Health Inspection Service, Animal Care (USDA, APHIS, AC) offers the following clarification and guidance:

This scenario raises numerous questions, but we will focus on the aspects that involve the USDA. The citations on the inspection report may be legitimate if there is a legal relationship between Great Eastern and Happy Trails, and there is activity covered by the Animal Welfare Act occurring at the wildlife rehabilitation organization. If Great Eastern believes the citations are in error, however, then USDA would encourage the university to discuss this situation and the findings documented in the inspection report with the inspector at the time of the exit interview. If the disagreement is not resolved by that discussion, Great Eastern may then decide to make a formal appeal of the citations.

There is a 21-day holding period after the inspector issues a report during which the facility may appeal any citation ${ }^{1}$. The appeal process allows both Great Eastern and the USDA inspector to make their cases, and a USDA official will decide whether noncompliance exists. An appeal also delays public release of the inspection report until the concerns are resolved, at which time both the initial report and any subsequent amended report is released. Both reports are considered official government documents and must be made publicly available.

1. U.S. Department of Agriculture. Animal and Plant Health Service. Animal Care Resource Guide: Research Facility Inspection Guide. Section 7.8: Inspection Appeals Process (US Department of Agriculture, Washington, DC, 2001). <http://www.aphis.usda.gov/animal_welfare/downloads/ manuals/rig/section/7.8_rig.pdf>

\section{Chester Gipson, DVM}

Deputy Administrator

USDA, APHIS, AC 